

\title{
Badania podobrazi malarskich caravaggionistów na podstawie obrazów z polskich kolekcji muzealnych
}

\author{
MATEUSZ JASIŃSKI \\ Wydział Konserwacji i Restauracji Dzieł Sztuk, ASP w Warszawie \\ e-mail:mateusz.jasinski@cybis.asp.waw.pl \\ JERZY NOWOSIELSKI \\ Wydział Konserwacji i Restauracji Dzieł Sztuk, ASP w Warszawie \\ e-mail: jerzy.nowosielski@cybis.asp.waw.pl
}

Keywords: painitng support, baroque painting, caravaqescue, Caravaggio, painting techniques

Słowa kluczowe: podobrazia malarskie, malarstwo barokowe, caravaggionizm, Caravaggio, techniki malarskie

\begin{abstract}
Research on canvases and wooden supports used by Caravagesques based on paintings in Polish collections.

The research on Caravagesques paintings' grounds was conducted as part of an exploratory project: Technique and technology of caravaggisti paintings based on polish museum collections. The project was financed by National Science Centre (2013/09/N/ HS2/02116, PRELUDIUM V) and it is a subject of doctoral thesis carried out under prof. Jerzy Nowosielski's guidance.

The new aesthetics emerging from the style of Michealangelo Merisi, popularly known as Caravaggio, started a trend of imitating the rules of luminism, new forms and themes among artistic communities of Italy, Spain, the Netherlands, Germany and France. The artists adopted Caravaggio's technique rules although some local
\end{abstract}


artistic traces can be spotted in Caravagesques works. They frequently used thickly woven canvas, often diagonal, to achieve particular artistic effects. The most important aspect of Caravaggio and his imitators' works is the usage of the dark ground, which played a huge role in creating painting's tonal quality and faithfulness to the dramatic effect. The colours of the ground in particular artists' works may vary regarding colour and filler used. By an in-depth examination of paintings we can learn and compare of artist painting workshop working in different areas of Europe, who were under the strong influence of Caravaggio works.

The research was based on twenty-three works in the collections of Polish museums. The examination of fillers using a SEM-EDS method conducted on the cross-sections enabled to show similarities and differences between particular layers.

\section{Abstrakt}

Badania nad podłożami malarskimi caravaggionistów przeprowadzono w ramach projektu badawczego Technika i technologia obrazów caravaggionistów $w$ oparciu o polskie zbiory muzealne. Projekt został sfinansowany przez Narodowe Centrum Nauki (nr 2013/09/N/HS2/02116, PRELUDIUM V) i jest tematem rozprawy doktorskiej realizowanej pod kierunkiem prof. Jerzego Nowosielskiego.

Powstanie nowej estetyki za sprawą Michealangelo Merisiego zwanego Caravaggio spowodowało modę na naśladowanie zasad luminizmu, nowych form i tematów w środowiskach artystycznych Włoch, Hiszpanii, Niderlandów, Niemiec i Francji. Artyści przyjęli zasady warsztatowe od Caravaggia, jednak w użytych materiałach można doszukać się naleciałości z tradycji kręgów artystycznych, z których się wywodzili. Caravaggioniści najczęściej stosowali grubo tkane płótna, często o skośnym splocie, które służyły uzyskaniu określonych efektów artystycznych. Jednak jednym z najważniejszych aspektów technologii Caravaggia i jego naśladowców było użycie barwnych zapraw, które odgrywały ogromną rolę w budowaniu tonacji całego obrazu i oddaniu dramatyzmu przedstawianych scen. Kolory zapraw u poszczególnych artystów często różniły się dość znacznie między sobą i użytymi wypełniaczami.

Do badań wybrano 23 obrazów z polskich muzeów. Na szlifach stratygraficznych przeprowadzono badania wypełniaczy zapraw metodą SEM-EDS, co pozwoliło wykazać podobieństwa i różnice pomiędzy poszczególnymi warsztatami.

\section{Wprowadzenie}

Kiedy papiestwo dla uczczenia zwycięstwa nad ruchami reformacyjnymi ogłosiło rok 1600 rokiem świętym, Rzym znów stał się europejską stolicą kultury. Do Wiecznego Miasta przybywali artyści z całych Włoch, a także z innych krajów - Hiszpanii, Flandrii, Francji, Niemiec. Przybysze z różnych regionów i kultur, mówiący różnymi językami, wymieniali się wiedzą techniczno-technologiczną, ideami, doświadczeniem oraz wzorcami stylistycznymi i ikonograficznymi. W rezultacie w ciągu kilku lat stylistyka późnego 
manieryzmu odeszła w niepamięć, a rewolucja w malarstwie, którą wywołał Michelangelo Merisi (1571-1610) zwany Caravaggio, rozprzestrzeniła się po całej Europie ${ }^{1}$. Daleka od rygorystycznych akademickich zasad twórczość Caravaggia otworzyła przed młodymi twórcami szanse dobrego i wczesnego rozpoczęcia kariery i często była powodem ich przybycia do Rzymu².

Zjawisko artystyczne polegające na naśladowaniu, interpretacji, kontynuacji, cytowaniu dzieł tego malarza weszło do historii sztuki pod nazwą caravaggionizmu. W pierwszym okresie rozwoju ograniczało się ono do Rzymu. W drugiej dekadzie XVII wieku na czoło rzymskiego środowiska caravaggionistów wysunęli się cudzoziemcy: Holendrzy, Flamandowie, Francuzi i Hiszpanie. Po roku 1620 to międzynarodowe środowisko zaczęło się stopniowo rozpraszać, a opuszczający Rzym artyści propagowali sztukę Caravaggia w całej Europie. Głównym ośrodkiem ruchu we Włoszech stał się wtedy Neapol. Za jego pośrednictwem idee Merisiego dotarły na Półwysep Iberyjski, a grupa katolickich artystów z Utrechtu przeniosła je na północ kontynentu ${ }^{3}$.

Obrazy Caravaggia były i są nadal poddawane licznym, coraz to nowym analizom zarówno w obszarze historii sztuki, jak i pod kątem technologii i technik malarskich. Twórczość jego naśladowców pozostaje wciąż na uboczu głównych zainteresowań badaczy. W polskich zbiorach muzealnych nie ma żadnego dzieła Caravaggia, są natomiast liczne obrazy caravaggionistów. Ich prace były zwykle rozpatrywane na tle historii sztuki, jeśli zaś analizowano je szerzej w aspekcie technik malarskich, skupiano się głównie na szukaniu zmian kompozycji na rentgenogramach i reflektografiach.

W literaturze przez lata narosły mity na temat sposobów pracy Caravaggia. Opierając się na słowach jego pierwszego biografa Giulia Manciniego ${ }^{4}$, który twierdził, że artysta pracował bezpośrednio na płótnie, bez żadnych rysunków, wnioskowano, że nie przywiązywał on wielkiej wagi do technologii malarskiej i przygotowania podobrazi ${ }^{5}$. Dopiero współcześnie prowadzone

1 Rosella Vodret i Belinda Granata, “Not Only Caravaggio”, w Caravaggio’s Rome 1600-1630, red. Rosella Vodret, vol. 1 (Rome: Museo Nazionale di Palazzo Venezia, 2012), 21.

2 Vodret i Granata, "Not Only Caravaggio", 65.

3 Jan Białostocki, Caravaggio (Warszawa: Wydawnictwo Sztuka, 1955), 46.

4 Giulio Mancini (ur. 21 II 1559 w Sienie, zm. 22 VIII 1630 w Rzymie) - włoski lekarz, kolekcjoner i krytyk sztuki, marszand i pisarz. W latach 1617- 1621 napisał dzieło Considerazioni sulla pittura, które jest obecnie cennym źródłem informacji na temat włoskiej sztuki początku XVII w. i artystów takich jak Caravaggio i Annibale Carracci. Zob. Maria Rzepińska, Historia koloru w dziejach malarstwa europejskiego (Warszawa: Arkady, 1989), 209, 264.

5 Vodret i Granata,"Not Only Caravaggio", 65. 
badania pokazują, jak wielką rolę w pracy Caravaggia i jego naśladowców odgrywało przygotowanie podobrazia i sam proces malowania, doskonale bowiem wiedzieli, jakich środków muszą użyć, by osiągnąć określone efekty artystyczne. Obrazy caravaggionistów, mimo wielu cech wspólnych dla całego nurtu, wykazują odrębności wynikające z tradycji malarstwa terenów, z których się wywodzili i gdzie tworzyli. Różnice te dotyczą tematów, ale także stosowanych materiałów.

Celem niniejszego artykułu jest przedstawienie wyników interdyscyplinarnych badań nad techniką i technologią przygotowywania podobrazi przez caravaggionistów ${ }^{6}$. Badaniom poddano dwadzieścia obrazów z czterech polskich muzeów ${ }^{7}$. Szczegółowe wyniki zestawione zostały w tablicy 1 .

\section{Metody badawcze}

W pracy badawczej zostały zastosowane nieniszczące metody obrazowania, wykorzystujące następujące rodzaje promieniowania: ultrafioletowe (ocena fluorescencji powierzchni obrazu wzbudzonej promieniowaniem ultrafioletowym), podczerwone (ocena warstw spodnich przy użyciu reflektografii w podczerwieni), Roentgena (rentgenografia) oraz widzialne (fotografia, mikro- i makrofotografia). Przy wstępnej analizie składu pierwiastkowego, będącego podstawą w procesie identyfikacji pigmentów i wypełniaczy warstw malarskich, posłużono się nieinwazyjną metodą badawczą, korzystając z przenośnego spektrometru fluorescencji rentgenowskiej (portable XRF). Do badań stratygraficznych, identyfikacji pigmentów i spoiw włączono także metody instrumentalne, wymagające pobrania z obiektów niewielkich próbek. Analizę składu pierwiastkowego przeprowadzono przy udziale skaningowego mikroskopu elektronowego sprzężonego ze spektrometrem dyspersji energii promieniowania rentgenowskiego (SEM-EDS), natomiast do analizy spoiw użyto spektroskopii absorpcyjnej w podczerwieni (FTIR) oraz chromatografii gazowej w połączeniu ze spektrometrią mas (GC-MS). W celu zidentyfikowania rodzajów płócien podobrazi próbki nici poddano obserwacji mikroskopowej i pomiarom w świetle odbitym, wykonano próbę

6 Badania zostały przeprowadzone w ramach projektu badawczego Technika i technologia obrazów caravaggionistów w oparciu o polskie zbiory muzealne (2013/09/N/HS2/02116, PRELUDIUM V) sfinansowanego przez Narodowe Centrum Nauki.

7 Muzeum Narodowego w Warszawie, Muzeum Narodowego w Poznaniu, Muzeum Pałacu Króla Jana III w Wilanowie i Muzeum Lubelskiego w Lublinie. 
spalania, reakcję z floroglucyną, test skręcania oraz barwienie w odczynniku Herzberga i w glicerynie.

\section{Przygotowanie podobrazi przez Caravaggia}

Sposób przygotowania podobrazia rzutuje na całą pracę artysty, efekt końcowy i odbiór malowidła. Błędy technologiczne popełnione w trakcie kładzenia zaprawy mogą źle wpłynąć na stan zachowania obrazu w przyszłości. Dlatego dawni artyści przykładali wielką wagę do wykonania podłoża malarskiego, dbając o odpowiedni dobór płótna, przeklejenie i rodzaj zaprawy. Metoda zaprawiania płótna i kolor zaprawy odgrywały znaczącą rolę przy wyborze metody malowania. Caravaggio przygotowywał podobrazia w taki sposób, aby na malowidle nie pojawiały się refleksy - było to szczególnie istotne przy obrazach tenebrystycznych, w których dużą część kompozycji stanowiły ciemne tła.

Przygotowując nowe podobrazia, nawet dużych formatów, Caravaggio starał się naciągać płótno bez konieczności zszywania dwóch brytów, ograniczając do minimum liczbę ewentualnych szwów, a jeśli nie dało się ich uniknąć, starał się, aby istotne elementy kompozycji nie wypadały na łączeniach. Szczególnie w późnym okresie twórczości preferował szorstką fakturę, jaką dawał gęsty i ścisły splot. Zdarzało mu się wykorzystywać nieukończony obraz jako podobrazie, ale zamalowując stare malowidło zawsze obracał płótno w przeciwnym kierunku, aby spodnia kompozycja nie przeszkadzała w trakcie pracy ${ }^{8}$. Płótna przeklejał prawdopodobnie różnego rodzaju klejami zwierzęcymi. De Mayerne zalecał klej skórny lub rybi, przestrzegając, że zbyt wysokie stężenie klejów podatnych na wchłanianie wilgoci prowadzi do dużych napięć 9 .

Jedną z cech technologii Caravaggia i jego naśladowców było użycie barwionych, zazwyczaj ciemnych zapraw. Na taki wybór - i szerzej na styl i technikę artysty - miało zapewne wpływ jego północnowłoskie pochodzenie (był Lombardczykiem). Kształcił się bowiem w Mediolanie u Simone Peterzana,

8 Claudio Seccaroni i Cecilia F. Cassacia, “A New Survey of Caravaggio’s Canvases and Preparatory Layers: Materials and Aesthetic Effects”, w Caravaggio's Painting Technique. Proceedings of the CHARISMA workshop, Firenze, 17 September 2010, red. Andrea Gelazzi (Firenze: Nardini Editore, 2012), 59-62.

9 Théodore de Mayerne, "Pictoria, Sculptoria, Tinctoria et guae subaltern rum atrium", w Gudrun Bishop, Das de Mayerne-Manuskript, Die Rezepte der Werkstoffe, Maltechniken und Gemalderestaurierung (Munchen: Siegl, 2002), 200. 
który z kolei uczył się u Tycjana ${ }^{10}$. Caravaggio nie był pierwszym malarzem, który stosował barwne grunty, nauczył się tego ze szkoły lombardzkiej. Dzięki niemu jednak stały się one bardziej znane i wykorzystywane do oddania dramatyzmu przedstawianych scen ${ }^{11}$.

Wyniki badań obrazów Caravaggia z różnych okresów wyraźnie pokazują, że kolor stosowanych przezeń zapraw ewoluował od zielonkawych (np. Chory Bachus, 1596, Galeria Borghese) przez oranżowoczerwone po ciemnobrązowe (np. Św. Hieronim, 1608, Galeria Borghese). Na przykład Chłopiec z jaszczurka (1595-1600, National Gallery w Londynie) namalowany został na brązowej zaprawie na bazie pigmentów ziemnych z dodatkiem bieli ołowiowej, Wieczerza w Emaus (1601, National Gallery w Londynie) na zaprawie o podobnym składzie, ale z dodatkiem kredy, Męczeństwo św. Mateusza (1599-1600, kościół San Luigi dei Francesi w Rzymie) zaś z dodatkiem węglanu wapnia (nie określono, w jakiej postaci). Malarz dodawał więc do zapraw, zamiennie lub w mieszaninach, wypełniacz w postaci kredy lub innego węglanu wapnia bądź bieli ołowiowej. Nanosił zaprawę na płótno zazwyczaj nie pędzlem, a za pomocą noża lub szpachli.

Przeważnie Caravaggio kładł zaprawę na płótno w dwóch warstwach, przy czym pierwsza, spodnia, w oranżowoczerwonawym kolorze (ochra czerwona z dodatkiem żółtej ziemi) była często jaśniejsza, wierzchnia zaś, kładziona cieniej, dużo ciemniejsza (na bazie dużych ilości czerwonej ochry i czerni organicznej $)^{12}$. W okresie rzymskim (1600-1606?) dodawał do zaprawy między innymi piasek, aby nadać podłożu szorstkośćn ${ }^{13}$. Badania obrazów wykazały ponadto, że niekiedy izolował zaprawę wcierając w nią olej; zabieg ten miał pewnie na celu zmniejszenie chłonności gruntu, wywołanej obecnością kredy lub innego węglanu wapnia ${ }^{14}$. Występujące niekiedy w zaprawach jego obrazów niewielkie ilości zieleni miedziowej i błękitów oraz cynobru znalazły się tam prawdopodobnie jako zanieczyszczenia lub dodat-

10 Larry Keith, “Three Paintings by Caravaggio”, National Gallery Technical Bulletin 19 (1998): 38.

11 Ashok Roy, “Caravaggio's Influence in the North”, w Caravaggio’s Painting Technique, 87.

12 Marco Ciatti i Carlo Lalli, "Caravaggio's the Behanding of Saint John the Baptist in Malta. Investigation into Execution, Technique, Style, and Restoration,” w Caravaggio's Painting Technique, 13.

13 Seccaroni i Cassacia, "A New Survey of Caravaggio’s Canvases”, 63.

14 Tego typu izolację zastosowano m.in. w obrazie Męczeństwo św. Mateusza. Zob. Giancarlo Sidoti, Fabio Talarico i Giuseppina Vigliano, “Caravaggio’s Painting Technique Through the Study of Cross-Sections: Optical Microscopy Survey and SEM-EDS Analyses”, w Caravaggio's Painting Technique, 72. 
ki farby z palety ${ }^{15}$. Była to powszechna praktyka, stosowana między innymi w pracowni Tintoretta, gdzie do przygotowania ciemnych zapraw używano resztek farb zeskrobywanych pod koniec dnia pracy z palet ${ }^{16}$, dodawano też osad z pojemników z olejem, w których przetrzymywano pędzle. Taki podkład zawierał w swoim składzie wiele pigmentów i szybko zasychał, ponieważ olej był już wystarczająco długo wystawiony na powietrze, by zainicjowany został proces jego polimeryzacji ${ }^{17}$.

\section{Wyniki badań}

Nie udało się objąć analizą płócien użytych na podobrazia we wszystkich wybranych obrazach ze względu na to, że przeważnie są one zdublowane, często z obciętymi krajkami, przez co możliwość pobrania materiału do badań jest ograniczona. Najczęściej jako podłoże stosowano tkaninę lnianą. Na podstawie oglądu wzrokowego lica oraz rentgenogramów można stwierdzić, że w badanych obrazach caravaggionistów dominują grubo tkane płótna o splocie płóciennym prostym. Skośny splot płótna występuje w obrazie Antiveduta Grammatiki oraz Francesca de Zurbarana ${ }^{18}$. Obraz Cecca del Caravaggia wykonany został na płótnie konopnym, przy czym malarz użył podobrazia z już zaczętą inną pracą, ale nie obrócił go, jak czynił to Caravaggio, i wykorzystał część wcześniejszej kompozycji. Cienkie płótna o gęstym splocie preferował Bernardo Cavallino, malarz obrazów o mniejszym formacie, gdyż widoczny gren płótna przeszkadzałby mu w operowaniu subtelnymi pociągnięciami pędzla, z których słynął. Caravaggioniści neapolitańscy, podobnie jak i Caravaggio pod koniec życia, wybierali szorstkie podłoża i pracując nad kompozycją wykorzystywali ich strukturę. Obrazy Mattii Pretiego (fot. 1), Matthiasa Stoma, Jusepe de Ribery namalowane zostały właśnie na takich podłożach. Ze wszystkich przebadanych obrazów jedynie Król Dawid grający na harfie w otoczeniu aniołów Hendricka Ter Brugghena ma płócienne

15 Claudio Falcucci, "Practices and Processes, from Odescalchi Conversion of Saint Paul to the Adoration of Shepherds”, w Caravaggio's Painting Technique, 31.

16 Grażyna Bastek, Warsztaty weneckie $w$ drugiej połowie XVi w XVI wieku (Warszawa: Wydawnictwo UW, 2011), 263.

17 Margriet van Eikem Hommes, Changing Pictures. Discoloration in 15th-17th-Century Oil Paintings (London: Archetype Publications, 2004), 37.

18 Anna Michnikowa, „Badania technologiczne obrazu Francisco de Zurbarana, Madonna Różańcowa adorowana przez kartuzów, nr inw. MNPFR 433” (dokumentacja badań, Poznań 2012, Archiwum MN w Poznaniu). 
podobrazie zszyte z dwóch kawałków materiału. Dotychczas uważano dodany pas płótna w górnej partii obrazu za wtórny, badania wykazały jednak, że jest to autorskie poszerzenie kompozycji, wprowadzone już na etapie przygotowywania podobrazia ${ }^{19}$.

Około 1600 roku w Niderlandach w powszechnym użyciu były nadal drewniane podobrazia z zaprawą kredowo-klejową. Płótno jako podłoże było rzadziej stosowane niż we Włoszech. Dopiero pojawienie się nowej estetyki caravaggionizmu, preferującej ciemne zaprawy, przyczyniło się do stopniowego wprowadzenia płótna jako podłoża malarskiego ${ }^{20}$. W zbiorach Muzeum Pałacu Króla Jana III w Wilanowie znajdują się dwa obrazy młodego Jana Lievensa (Młody mężczyzna zapalający żagiew oraz Młody mężczyzna z fajka dmuchający na żar) namalowane w duchu caravaggionistycznym, lecz na podobraziach dębowych. Kompozycje opracowano na jasnych zaprawach kredowo-klejowych pokrytych złocistą imprimaturą. W latach 1626-1631 Lievens dzielił pracownię z Rembrandtem van Rijn i obaj w młodzieńczej fascynacji utrechckim caravaggionizmem tworzyli obrazy w stylu Ter Brugghena i Gerrita van Honthorsta, wykorzystując przy tym doświadczenia technologiczne malarstwa holenderskiego ${ }^{21}$. Caravaggio namalował jedynie kilka obrazów na podobraziach drewnianych, wolał jednak przykleić do deski płótno od strony lica (np. Głowa Meduzy, ok. 1596, Galeria Uffizi).

Caravaggioniści utrechccy stosowali z reguły zaprawy kładzione dwuwarstwowo. Ter Brugghen (Piłat umywający ręce) i Honthorst (Sąd Midasa / Koncert) nakładali wpierw warstwę oranżowobrązową, a na wierzchu szarą lub szarobrązowąą2. Podobną zaprawę ma obraz Król Dawid grający na harfie... Ter

19 Skład i kolor zaprawy jest identyczny na obu kawałkach płótna. Zob. Elżbieta Jeżewska, „Opracowanie budowy technologicznej w zakresie stratygrafii warstw oraz użytych pigmentów i wypełniaczy na podstawie próbek pobranych z obrazu autorstwa Hendricka Ter Brugghena pt. Król Dawid grający na harfie i chór aniołów" (dokumentacja badań, Warszawa 2015, Archiwum Katedry Technik i Technologii Malarstwa Sztalugowego WKRiDS ASP w Warszawie).

20 Elisabeth Martin, "Grounds on Canvas 1600-1640 in Various European Artistic Centers", w Preparation for Painting: The Artist's Choice and its Consequences, red. Joyce H. Townsend et al. (London: Archetype Publications, 2010), 59.

21 Mateusz Jasiński, Badania dwóch obrazów Jana Lievensa:Młody mężczyzna zapalający żagiew, 1625; Młody mężczyzna z fajką dmuchający na żar, 1625;ze zbiorów Muzeum Pałacu Króla Jana III w Wilanowie http://www.wilanow-palac.pl/badania_dwoch_obrazow_jana_lievens_a_z_kolekcji_wilanowskiej_cenne_obrazy_w_nowym_swietle.html. Dostęp 22 kwietnia 2018.

22 Potwierdzają to badania innych obrazów tych artystów, choćby Koncert (1626), Mężczyzna grający na lutni (1624) Ter Brugghena oraz Św. Sebastian (ok.1623) Honthorsta ze zbiorów National Gallery w Londynie. Zob. Roy, “Caravaggio’s Influence in the North”, 86-87. 
Brugghena ${ }^{23}$ ze zbiorów Muzeum Narodowego w Warszawie (fot. 2). Zaprawa taka jest chłodniejsza w kolorze i jaśniejsza od stosowanych przez Caravaggia i jego włoskich naśladowców, przez co efekt chiaroscuro jest dużo mniejszy.

W odróżnieniu od Włochów malarze z krajów na północ od Alp częściej zastępowali w zaprawach różne odmiany węglanu wapnia ${ }^{24}$ kredą. W obrazie Gra w karty flamandzkiego malarza Theodora Romboutsa zaprawa ma jasnokremowy odcień uzyskany dzięki kredzie i niewielkiej ilości czerwonej ochry, czerni roślinnej oraz bieli ołowiowej (fot. 3$)^{25}$. W barwionych zaprawach kreda stanowiła z reguły 5-75\% masy, ale zdarzają się zaprawy, w których udział kredy sięga $90 \%{ }^{26}$.

Oprócz wypełniaczy w postaci kredy, różnych odmian węglanu wapnia oraz bieli ołowiowej najczęściej występującymi dodatkami nadającymi kolor zaprawie były czerwone i żółte ochry. Bardziej chłodny odcień uzyskiwano dodając czerń roślinną lub czerń kostną (fot. 4). Stosowano też inne pigmenty - żółcień cynowo-ołowiową, umbrę naturalną. Dodanie ziaren kwarcu miało na celu nadanie podłożu większej szorstkości ${ }^{27}$.

Nie udało się w pełni przebadać spoiw w zaprawach używanych przez caravaggionistów, ze względu na to, że obrazy poddawane były licznym konserwacjom i są przesycone licznymi impregnatami, co sprawia, że wyniki są niejednoznaczne. W większości badanych zapraw stwierdzono obecność kleju glutynowego oraz oleju schnącego. Artyści prawdopodobnie stosowali zaprawy emulsyjne na bazie klejów zwierzęcych z większym lub mniejszym dodatkiem oleju lub typowe dla siedemnastowiecznego malarstwa tłuste zaprawy olejne ${ }^{28}$. Niewykluczone, że w niektórych wypadkach obecność kleju może wiązać się z zanieczyszczeniem próbki pochodzącym z warstwy przeklejenia. Jednak w obrazach Cecca del Caravaggia (Męczeństwo św. Sebastiana) i Carla Dolciego (Św. Paweł Pustelnik) na przekrojach poprzecznych widoczna jest izolacja zaprawy, wykonana przez wtarcie oleju schnącego, która mogła służyć zmniejszeniu chłonności emulsyjnej zaprawy.

${ }^{23}$ Jeżewska, „Opracowanie [obrazu pt. Król Dawid grający na harfie i chór aniołów]”.

24 Kształt niektórych ziaren sugeruje obecność mączki marmurowej albo innej wysoko krystalicznej formy kalcytu.

25 Elżbieta Jeżewska, „Opracowanie budowy technologicznej w zakresie stratygrafii warstw oraz użytych pigmentów i wypełniaczy na podstawie próbek pobranych z obrazu autorstwa Theodora Romboutsa pt. Gra w karty” (dokumentacja badań, Warszawa 2015, Archiwum Katedry Technik i Technologii Malarstwa Sztalugowego WKRiDS ASP w Warszawie).

26 Martin, "Grounds on Canvas", 61-62.

27 Zob. tablica 1.

28 Erling Skaug, "Not Just Panel and Ground”, w Preparation for Painting, 24. 
Tablica 1 . Wykaz badanych obrazów z charakterystyką ich podobrazi i zapraw

\begin{tabular}{|c|c|c|c|}
\hline $\begin{array}{l}\text { Autor, tytuł obrazu, } \\
\text { czas powstania, } \\
\text { wymiary, nr inw. }\end{array}$ & $\begin{array}{c}\text { Rodzaj } \\
\text { podobrazia }\end{array}$ & $\begin{array}{l}\text { Liczba warstw, } \\
\text { kolor zaprawy }\end{array}$ & $\begin{array}{c}\text { Skład } \\
\text { zaprawy }\end{array}$ \\
\hline 1 & 2 & 3 & 4 \\
\hline \multicolumn{4}{|c|}{ RZYM } \\
\hline $\begin{array}{l}\text { Antiveduto Gramatica, } \\
\text { Madonna z Dzieciątkiem } \\
\text { i św. Anna, 1614-1617, } \\
115 x 145 \mathrm{~cm}, \\
\text { nr inw. M.Ob.653MNW }\end{array}$ & $\begin{array}{l}\text { płótno Iniane, } \\
\text { splot skośny }\end{array}$ & I brązowa ciepła & $\begin{array}{l}\text { węglan wapnia, } \\
\text { glinokrzemiany, czerń } \\
\text { roślinna, czerwona/żółta } \\
\text { ochra, biel ołowiowa, kwarc }\end{array}$ \\
\hline \multirow{2}{*}{$\begin{array}{l}\text { Cecco del Caravaggio } \\
\text { (Francesco Buoneri), } \\
\text { Męczeństwo św. Sebastiana, } \\
\text { I poł. XVII w., 124x162,5 cm, } \\
\text { nr inw. M.Ob. } 645 \text { MNW }\end{array}$} & \multirow[t]{2}{*}{$\begin{array}{l}\text { płótno konopne, } \\
\text { splot prosty }\end{array}$} & Il beżowa - ciepła & \multirow[t]{2}{*}{$\begin{array}{l}\text { I, II - węglan wapnia, } \\
\text { czerwona/żółta ochra, } \\
\text { krzemionka? }\end{array}$} \\
\hline & & I beżowa - ciepła & \\
\hline \multirow{2}{*}{$\begin{array}{l}\text { Gerrit van Honthorst, } \\
\text { Sąd Midasa/Koncert, } \\
1610-1620,163 \times 90 \mathrm{~cm} \text {, } \\
\text { nr inw. S/Mal/1587/ML }\end{array}$} & \multirow{2}{*}{$\begin{array}{l}\text { płótno Iniane, } \\
\text { splot prosty }\end{array}$} & $\begin{array}{l}\text { Il ciemnobrązowa - } \\
\text { chłodna }\end{array}$ & $\begin{array}{l}\text { czerń kostna, węglan } \\
\text { wapnia, biel ołowiowa, } \\
\text { czerwona/żółta ochra }\end{array}$ \\
\hline & & I brazowa - ciepła & $\begin{array}{l}\text { węglan wapnia, czerwona } \\
\text { ochra bogata w substancje } \\
\text { ilaste }\end{array}$ \\
\hline $\begin{array}{l}\text { Nicolas Tournier, } \\
\text { Dawid z głową Goliata, } \\
\text { II poł. lat } 20 . \text { XVII w., } \\
91 \times 72 \mathrm{~cm} \text {, } \\
\text { nr inw. M.Ob. } 655 \text { MNW }\end{array}$ & $\begin{array}{l}\text { płótno Iniane, } \\
\text { splot prosty }\end{array}$ & I brązowa & $\begin{array}{l}\text { czerwona ochra, węglan } \\
\text { wapnia, czerń roślinna, } \\
\text { niewielkie ilości bieli } \\
\text { ołowiowej }\end{array}$ \\
\hline \multirow{2}{*}{$\begin{array}{l}\text { Willem Drost, } \\
\text { Starzec z księga, } \\
\text { ok. } 1655-1660,86 \times 74 \mathrm{~cm} \text {, } \\
\text { nr inw. M.Ob. } 1896 \text { MNW }\end{array}$} & \multirow{2}{*}{$\begin{array}{l}\text { płótno Iniane, } \\
\text { splot prosty }\end{array}$} & $\begin{array}{l}\text { Il czerwono- } \\
\text {-brązowa }\end{array}$ & \multirow{2}{*}{$\begin{array}{l}\text { I, II - czerwona ochra, } \\
\text { umbra naturalna, węglan } \\
\text { wapnia, śladowe ilości bieli } \\
\text { ołowiowej }\end{array}$} \\
\hline & & I czerwona & \\
\hline
\end{tabular}


Cd. tab. 1

\begin{tabular}{|c|c|c|c|}
\hline 1 & 2 & 3 & 4 \\
\hline \multicolumn{4}{|c|}{ NEAPOL } \\
\hline \multirow{3}{*}{$\begin{array}{l}\text { Jusepe de Ribera, } \\
\text { Św. Sebastian, } \\
\text { lata } 30 . \text { XVII w., } \\
\text { 142,5x187,5 cm, } \\
\text { nr inw. M.Ob.650 MNW }\end{array}$} & \multirow{3}{*}{$\begin{array}{l}\text { płótno Iniane, } \\
\text { splot prosty }\end{array}$} & $\begin{array}{l}\text { Ill brązowa, ciepły } \\
\text { odcień }\end{array}$ & \multirow{3}{*}{$\begin{array}{l}\text { I, II, III - czerń roślinna, } \\
\text { węglan wapnia, } \\
\text { czerwona/żółta ochra } \\
\text { bogata w substancje } \\
\text { ilaste, niewielka ilość bieli } \\
\text { ołowiowej }\end{array}$} \\
\hline & & $\begin{array}{l}\text { Il brązowa, ciepły } \\
\text { odcień }\end{array}$ & \\
\hline & & $\begin{array}{l}\text { I brazowa ,ciepły } \\
\text { odcień }\end{array}$ & \\
\hline $\begin{array}{l}\text { Jusepe de Ribera, } \\
\text { Św. Jan Chrzciciel } \\
\text { na pustkowiu, } \\
\text { Il poł. lat } 30 . \text { XVII w., } \\
\text { 178x161 cm, } \\
\text { nr inw. MNP Mo1282 }\end{array}$ & $\begin{array}{l}\text { gęsto tkane } \\
\text { płótno Iniane, } \\
\text { splot prosty }\end{array}$ & I brazowa & $\begin{array}{l}\text { czerwona/żółta ochra } \\
\text { bogata w substancje ilaste, } \\
\text { węglan wapnia, kwarc }\end{array}$ \\
\hline $\begin{array}{l}\text { Bernardo Cavallino, } \\
\text { Sen św. Józefa, } \\
\text { I poł. lat } 40 . \text { XVII w., } \\
\text { 102x75 cm, } \\
\text { nr inw. M.Ob. } 640 \text { MNW }\end{array}$ & $\begin{array}{l}\text { płótno Iniane, } \\
\text { splot prosty }\end{array}$ & I beżowobrązowa & $\begin{array}{l}\text { węglan wapnia, czerwona/ } \\
\text { żółta ochra, niewielkie ilości } \\
\text { bieli ołowiowej i czerni } \\
\text { roślinnej }\end{array}$ \\
\hline \multirow{2}{*}{$\begin{array}{l}\text { Matthias Stom, } \\
\text { Św. Piotr w modlitwie, } \\
\text { 1633-1640, 104x128,5 cm, } \\
\text { nr inw. M.Ob. } 1890 \text { MNW }\end{array}$} & \multirow{2}{*}{$\begin{array}{l}\text { płótno Iniane, } \\
\text { splot prosty }\end{array}$} & Il beżowobrązowa & \multirow{2}{*}{$\begin{array}{l}\text { I, II - czerwona/żółta ochra, } \\
\text { kreda, niewielka ilość bieli } \\
\text { ołowiowej }\end{array}$} \\
\hline & & I beżowobrązowa & \\
\hline $\begin{array}{l}\text { Mattia Preti, } \\
\text { Pokłon pasterzy, } \\
\text { ok. 1645, 148x197 cm, } \\
\text { nr inw. M.Ob.666 MNW }\end{array}$ & $\begin{array}{l}\text { grubo tkane } \\
\text { płótno Iniane, } \\
\text { splot prosty }\end{array}$ & I brazowa & $\begin{array}{l}\text { węglan wapnia, czerwona } \\
\text { i żółta ochra }\end{array}$ \\
\hline $\begin{array}{l}\text { Luca Giordano, } \\
\text { Prometeusz, } \\
\text { II poł. XVII w., } 186,7 \times 160 \mathrm{~cm} \text {, } \\
\text { nr inw. M.Ob. } 308 \text { MNW }\end{array}$ & $\begin{array}{l}\text { płótno Iniane, } \\
\text { splot prosty }\end{array}$ & I brązowa & $\begin{array}{l}\text { czerwona/żółta ochra, } \\
\text { węglan wapnia, niewielkie } \\
\text { ilości bieli ołowiowej }\end{array}$ \\
\hline $\begin{array}{l}\text { Gaspare Traversi, } \\
\text { Scena z legendy Hioba, } \\
\text { I poł. XVIII w., } 84 \times 102 \mathrm{~cm} \text {, } \\
\text { nr inw. M.Ob. } 807 \text { MNW }\end{array}$ & $\begin{array}{l}\text { płótno Iniane, } \\
\text { splot prosty }\end{array}$ & I ciemnoczerwona & $\begin{array}{l}\text { czerwona i żółta ochra, } \\
\text { czerń roślinna, węglan } \\
\text { wapnia }\end{array}$ \\
\hline
\end{tabular}


Cd. tab. 1

\begin{tabular}{|c|c|c|c|}
\hline 1 & 2 & 3 & 4 \\
\hline \multicolumn{4}{|c|}{ FLORENCJA } \\
\hline $\begin{array}{l}\text { Carlo Dolci, } \\
\text { Św. Paweł Pustelnik, } \\
\text { przed 1648, 168,5x132 cm, } \\
\text { nr inw. M.Ob. } 647 \text { MNW }\end{array}$ & $\begin{array}{l}\text { płótno Iniane, } \\
\text { splot prosty }\end{array}$ & I brązowa ciepła & $\begin{array}{l}\text { węglan wapnia, czerwonal } \\
\text { żółta ochra, czerń } \\
\text { organiczna?, czerń roślinna, } \\
\text { niewielkie ilości bieli ołowiowej }\end{array}$ \\
\hline \multicolumn{4}{|c|}{ UTRECHT } \\
\hline \multirow{2}{*}{$\begin{array}{l}\text { Hendrick Ter Brugghen, } \\
\text { Król Dawid grający na harfie } \\
\text { w otoczeniu aniołów, } \\
\text { 1628, } 150 \times 190 \mathrm{~cm} \text {, } \\
\text { nr inw. } 529 \text { MNW }\end{array}$} & \multirow{2}{*}{$\begin{array}{l}\text { płótno Iniane } \\
\text { zszyte z dwóch } \\
\text { kawałków, splot } \\
\text { prosty }\end{array}$} & II szara & $\begin{array}{l}\text { węglan wapnia, biel } \\
\text { ołowiowa, umbra naturalna, } \\
\text { czerń roślinna i kostna }\end{array}$ \\
\hline & & I czerwona & $\begin{array}{l}\text { czerwona/żółta ochra, } \\
\text { węglan wapnia, biel } \\
\text { ołowiowa, niewielkie ilości } \\
\text { czerni roślinnej }\end{array}$ \\
\hline \multirow{3}{*}{$\begin{array}{l}\text { Hendrick Ter Brugghen, } \\
\text { Piłat umywający ręce, } \\
\text { ok. } 1617-1618 \text {, } \\
\text { 100,7x128,7 cm, } \\
\text { nr inw. S/M/1611/ML }\end{array}$} & \multirow{3}{*}{$\begin{array}{l}\text { płótno Iniane, } \\
\text { splot prosty }\end{array}$} & III szara & $\begin{array}{l}\text { biel ołowiowa, węglan wapnia, } \\
\text { żółta ochra, czerń kostna }\end{array}$ \\
\hline & & $\begin{array}{l}\text { II żółto- } \\
\text {-pomarańczowa }\end{array}$ & $\begin{array}{l}\text { żółta ochra, węglan wapnia, } \\
\text { biel ołowiowa }\end{array}$ \\
\hline & & $\begin{array}{l}\text { I brązowo- } \\
\text { pomarańczowa }\end{array}$ & $\begin{array}{l}\text { Czerwona i żółta ochra, } \\
\text { kwarc, niewielkie ilości bieli } \\
\text { ołowiowej i kredy }\end{array}$ \\
\hline \multicolumn{4}{|c|}{ WENECJA } \\
\hline \multirow[b]{2}{*}{$\begin{array}{l}\text { Johan Carl Loth, } \\
\text { Sylen, } \\
\text { II poł. XVII w., } 130 \times 100 \text { cm, } \\
\text { nr inw. M.Ob. } 183041 \text { MNW }\end{array}$} & \multirow[b]{2}{*}{$\begin{array}{l}\text { płótno Iniane, } \\
\text { splot prosty }\end{array}$} & Il pomarańczowa & $\begin{array}{l}\text { czerwona/żółta ochra, } \\
\text { węglan wapnia, niewielka } \\
\text { ilość bieli ołowiowej }\end{array}$ \\
\hline & & I czerwonobrązowa & $\begin{array}{l}\text { czerwona/żółta ochra, } \\
\text { węglan wapnia (mączka } \\
\text { marmurowa?), tłuczona } \\
\text { ceramika?, w małej ilości } \\
\text { biel ołowiowa i żółcień } \\
\text { cynowo-ołowiowa }\end{array}$ \\
\hline \multirow{2}{*}{$\begin{array}{l}\text { Johan Carl Loth, } \\
\text { Śmierć Katona*, } \\
\text { II poł. XVII w., 125x105 cm, } \\
\text { nr inw. M.Ob. } 2033 \text { MNW }\end{array}$} & \multirow[b]{2}{*}{$\begin{array}{l}\text { płótno Iniane, } \\
\text { splot prosty }\end{array}$} & II brunatna & umbra, żółta ochra \\
\hline & & I jasnougrowa & $\begin{array}{l}\text { żółta ochra } \\
\text { z domieszką umbry }\end{array}$ \\
\hline
\end{tabular}

Obraz Lotha został przebadany przez Grażynę Bastek i Grzegorza Janczarskiego przy okazji wystawy „Serenessima. Światło Wenecji”. Zob. Antoni Ziemba, „Johan Carl Loth, Śmierć Katona”, w Serenissima. Światło Wenecji. Dzieła mistrzów weneckich XIV-XVIII wieku ze zbiorów Muzeum Narodowego $w$ Warszawie $w$ świetle nowych badań technologicznych, historycznych i prac konserwatorskich, red. Grażyna Bastek i Grzegorz Janczarski (Warszawa: Muzeum Narodowe, 1999), 256. 
Cd. tab. 1

\begin{tabular}{|c|c|c|c|}
\hline 1 & 2 & 3 & 4 \\
\hline \multicolumn{4}{|c|}{ ANTWERPIA } \\
\hline $\begin{array}{l}\text { Theodor Rombouts, } \\
\text { Gra w karty, } \\
\text { I poł. XVII w., } 167,5 \times 233,5 \mathrm{~cm} \text {, } \\
\text { nr inw. M.Ob. } 575 \text { MNW }\end{array}$ & $\begin{array}{l}\text { płótno Iniane, } \\
\text { splot prosty }\end{array}$ & I kremowa & $\begin{array}{l}\text { kreda, niewielkie ilości } \\
\text { czerwonej ochry, czerni } \\
\text { roślinnej i bieli ołowiowej }\end{array}$ \\
\hline \multicolumn{4}{|c|}{ LEJDA } \\
\hline \multirow{2}{*}{$\begin{array}{l}\text { Jan Lievens, } \\
\text { Młody mężczyzna z fajką } \\
\text { dmuchający na żar, } \\
\text { ok.1526, } 82 \times 64 \mathrm{~cm}, \\
\text { nr inw. Wil.1526 }\end{array}$} & \multirow{2}{*}{ deska dębowa } & $\begin{array}{l}\text { Il złocista } \\
\text { imprimatura }\end{array}$ & ochra? \\
\hline & & I kremowa & kreda \\
\hline \multirow{3}{*}{$\begin{array}{l}\text { Jan Lievens, } \\
\text { Młody mężczyzna } \\
\text { zapalający żagiew, } \\
\text { ok. 1526, } 82 x 64 \mathrm{~cm} \text {, } \\
\text { nr inw. Wil.1526 }\end{array}$} & \multirow{3}{*}{ deska dębowa } & $\begin{array}{l}\text { III złocista } \\
\text { imprimatura }\end{array}$ & ochra? \\
\hline & & II żółtokremowa & biel ołowiowa \\
\hline & & I żółtokremowa & węglan wapnia \\
\hline \multicolumn{4}{|c|}{ SEWILA } \\
\hline \multirow{2}{*}{$\begin{array}{l}\text { Francisco de Zurbaran, } \\
\text { Madonna Różańcowa } \\
\text { adorowana przez kartuzów, } \\
\text { ok. 1638-1639, 325x196 cm, } \\
\text { nr inw. MNP FR } 433\end{array}$} & \multirow{2}{*}{$\begin{array}{l}\text { płótno Iniane, } \\
\text { splot skośny }\end{array}$} & II szara & $\begin{array}{l}\text { skład identyczny jak } \\
\text { warstwy I, różnica koloru } \\
\text { wynika z różnych proporcji } \\
\text { wypełniaczy }\end{array}$ \\
\hline & & I beżowa & $\begin{array}{l}\text { węglan wapnia, czerwonal } \\
\text { żółta ochra, kwarc lub } \\
\text { glinokrzemiany }\end{array}$ \\
\hline \multicolumn{4}{|c|}{ GENUA } \\
\hline $\begin{array}{l}\text { Simon Vouet, } \\
\text { Niedobrana para, } \\
1621,100 \times 75,5 \mathrm{~cm} \text {, } \\
\text { nr inw. } 642 \mathrm{MNW}\end{array}$ & $\begin{array}{l}\text { płótno Iniane, } \\
\text { splot prosty }\end{array}$ & I beżowobrązowa & $\begin{array}{l}\text { czerwona/żółta ochra } \\
\text { bogata w substancje ilaste, } \\
\text { węglan wapnia, niewielka } \\
\text { ilość bieli ołowiowej }\end{array}$ \\
\hline
\end{tabular}

ML - Muzeum Lubelskie w Lublinie; MNP - Muzeum Narodowe w Poznaniu; MNW - Muzeum Narodowe w Warszawie; Wil - Muzeum Pałacu Króla Jana III Sobieskiego w Wilanowie. Obrazy pogrupowano według miejsc, w których tworzyli artyści w momencie fascynacji caravaggionizmem. 


\section{Podsumowanie}

Wyniki badań jednoznacznie informują, że zakres kolorystyczny stosowanych zapraw był bardzo szeroki - od jasnobeżowych do ciemnobrązowych; na przykład u Merisiego ewolucja kolorystyczna zapraw stopniowo przebiegała od jasnych i chłodnych kolorów do ciemnych i ciepłych. Pokazuje to, jak naśladowcy Caravaggia przekształcali jego sztukę drogą własnych doświadczeń artystycznych.

Należy pamiętać, że caravaggionizm był modą, która przeminęła. Większość naśladowców tylko chwilowo przejęła styl swego mistrza, nie porzucając niektórych dawnych przyzwyczajeń. Pierwsi caravaggioniści, mający z reguły bezpośredni kontakt z mistrzem w Rzymie, byli pod silnym wpływem jego sztuki i osobowości. Niewykluczone, że mogli podpatrywać Caravaggia przy pracy i oglądać kolejne etapy powstawania obrazów. Artyści należący do drugiej generacji caravaggionistów, czyli urodzeni w okresie 1585-1600 i aktywni od drugiej dekady XVII wieku, nie mieli manierystycznych korzeni ani bezpośredniego kontaktu z Caravaggiem. Stworzyli swój styl przez kontakt z dziełami mistrza, przez asymilację zewnętrznych cech jego malowideł, czasem dodając własne, indywidualne rysy ${ }^{29}$.

Zarówno Caravaggio, jak i jego naśladowcy dobierali rodzaj grenu i splot płótna w zależności od takich czynników, jak format obrazu, funkcja, przeznaczenie oraz zamierzony efekt artystyczny. Unikali zszywania brytów płótna. Najczęściej występującym rodzajem tkaniny było płótno lniane o splocie prostym, gruntowane na tyle cienko, by jego faktura pozostała widoczna. Badania wykazały obecność różnych dodatków mających przydać podłożu większej szorstkości.

W podobraziach Caravaggia głównymi wypełniaczami zapraw były: żółta ochra, czerwona i brązowa ziemia, umbra, mieszane w różnych proporcjach z bielą ołowiową, węglanem wapnia, kwarcem i czernią węglową. Malarz wykorzystywał różne odmiany węglanu wapnia, w tym kredę ${ }^{30}$. W przebadanych obrazach caravaggionistów oprócz białych wypełniaczy typowymi dodatkami nadającymi kolor były czerwone i żółte ochry ${ }^{31}$, czernie, umbra naturalna, żołcień cynowo-ołowiowa, glinki, tłuczona ceramika ${ }^{32}$ i ziarna kwarcu.

\footnotetext{
29 Vodret i Granata, “Not Only Caravaggio”, 51, 60.

30 Falcucci, "Practices and Processes", 31.

31 Wykryte we wszystkich badanych obrazach.

32 Kształt dużych ziaren w szlifie stratygraficznym może sugerować dodatek czerwonej ceramiki.
} 
Zestaw pigmentów używanych przez nich do nadania koloru był więc bardzo zbliżony do zestawu mistrza. Jak pokazują obrazy Lievensa i Romboutsa, na bardzo jasnej zaprawie również można było stworzyć caravaggionistyczny obraz, nawet o tenebrystycznym charakterze.

Zaprawa w obrazach tenebrystycznych odgrywała znaczącą rolę, jej kolor był wykorzystywany w półtonach. Z biegiem czasu zmienił się współczynnik załamania światła pigmentu i spoiwa, farby stały się bardziej transparentne, przez co pogłębił się kontrast między światłem a cieniem. Dlatego prace caravaggionistów nie wyglądają już dokładnie tak jak w chwili namalowania ${ }^{33}$. Obecnie odziaływanie ciemnej zaprawy w niektórych obrazach jest znacznie większe, kolorowy grunt stał się bardziej widoczny, zmieniając optyczny odbiór malowidła ${ }^{34}$.

\section{Bibliografia}

Bastek, Grażyna. Warsztaty weneckie w drugiej połowie XV i w XVI wieku. Warszawa: Wydawnictwo UW, 2011.

Białostocki, Jan. Caravaggio. Warszawa: Wydawnictwo Sztuka, 1955.

Ciatti, Marco, i Carlo Lalli. “Caravaggio's the Behanding of Saint John the Baptist in Malta. Investigation into Execution, Technique, Style, and Restoration”. W Caravaggio's Painting Technique. Proceedings of the CHARISMA Workshop, Firenze, 17 September 2010, red. Andrea Gelazzi, 11-22. Firenze: Nardini Editore, 2012.

Falucci, Claudio. "Practices and Processes, from Odescalchi Conversion of Saint Paul to the Adoration of Shepherds". W Caravaggio's Painting Technique. Proceedings of the CHARISMA Workshop, Firenze, 17 September 2010, red. Andrea Gelazzi, 31-40. Firenze: Nardini Editore, 2012.

Hommes, Margriet van Eikem. Changing Pictures. Discoloration in 15th-17th-Century Oil Paintings. London: Archetype Publications, 2004.

Jasiński, Mateusz, Badania dwóch obrazów Jana Lievensa: Młody mężczyzna zapalający żagiew, 1625; Młody mężczyzna z fajką dmuchający na żar, 1625; ze zbiorów Muzeum Pałacu Króla Jana III w Wilanowie. http://www.wilanow-palac.pl/badania_dwoch_ obrazow_jana_lievens_a_z_kolekcji_wilanowskiej_cenne_obrazy_w_nowym_swietle. html. Dostęp 22 kwietnia 2018.

Jeżewska, Elżbieta. „Opracowanie budowy technologicznej w zakresie stratygrafii warstw oraz użytych pigmentów i wypełniaczy na podstawie próbek pobranych z obrazu autorstwa Hendricka Ter Brugghena pt. Król Dawid grający na harfie i chór aniołów”. Dokumentacja badań, Warszawa 2015, Archiwum Katedry Technik i Technologii Malarstwa Sztalugowego WKRiDS ASP w Warszawie.

33 Keith, “Three Paintings by Caravaggio", 39.

34 Van Eikem Hommes, Changing Pictures, 37. 
Jeżewska, Elżbieta. „Opracowanie budowy technologicznej w zakresie stratygrafii warstw oraz użytych pigmentów i wypełniaczy na podstawie próbek pobranych z obrazu autorstwa Theodora Romboutsa pt. Gra w karty”. Dokumentacja badań, Warszawa 2015, Archiwum Katedry Technik i Technologii Malarstwa Sztalugowego WKRiDS ASP w Warszawie.

Keith, Larry. “Three Paintings by Caravaggio”. National Gallery Technical Bulletin 19 (1998): 37-51.

Martin, Elisabeth. "Grounds on canvas 1600-1640 in various European artistic centers”. W Preparation for Painting: The Artist's Choice and its Consequences, red. Joyce H. Townsend, Tiarna Doherty, Gunnar Heydenreich, Jacqueline Ridge, 59-67. London: Archetype Publications, 2010.

Mayerne, Théodore de. "Pictoria, Sculptoria, Tinctoria et guae subaltern rum atrium”. W Gudrun Bishop, Das de Mayerne-Manuskript. Die Rezepte der Werkstoffe, Maltechniken und Gemalderestaurierung. Munchen: Siegl, 2002.

Michnikowa, Anna. „Badania technologiczne obrazu Francisco de Zurbarana, Madonna Różańcowa adorowana przez kartuzów, nr inw. MNPFR 433”. Dokumentacja badań, Poznań 2012, Archiwum MN w Poznaniu.

Roy, Ashok. “Caravaggio’s Influence in the North”. W Caravaggio’s Painting Technique. Proceedings of the CHARISMA Workshop, Firenze, 17 September 2010, red. Andrea Gelazzi, 85-94. Firenze: Nardini Editore, 2012.

Rzepińska, Maria. Historia koloru w dziejach malarstwa europejskiego. Warszawa: Arkady, 1989.

Seccaroni, Claudio, i Cecilia F. Cassacia. “A New Survey of Caravaggio’s Canvases and Preparatory Layers: Materials and Aesthetic Effects”. W Caravaggio's Painting Technique. Proceedings of the CHARISMA Workshop, Firenze, 17 September 2010, red. Andrea Gelazzi, 59-68. Firenze: Nardini Editore, 2012.

Sidoti, Giancarlo, Fabio Talarico, i Giuseppina Vigliano. “Caravaggio’s Painting Technique Through the Study of Cross-Sections: Optical Microscopy Survey and SEMEDS Analyses". W Caravaggio's Painting Technique. Proceedings of the CHARISMA Workshop, Firenze, 17 September 2010, red. Andrea Gelazzi, 69-78. Firenze: Nardini Editore, 2012.

Skaug, Erling. "Not Just Panel and Ground”. W Preparation for Painting: The Artist's Choice and its Consequences, red. Joyce H. Townsend, Tiarna Doherty, Gunnar Heydenreich, Jacqueline Ridge, 22-29. London: Archetype Publications, 2010.

Vodret, Rosella, i Belinda Granata. "Not Only Caravaggio”. W Caravaggio’s Rome 1600-1630, red. Rosella Vodret. T. 1, 21-95. Rome: Museo Nazionale di Palazzo Venezia, 2012.

Ziemba, Antoni. “Johan Carl Loth, Śmierć Katona”. W Serenissima. Światło Wenecji. Dzieła mistrzów weneckich XIV-XVIII wieku ze zbiorów Muzeum Narodowego w Warszawie $w$ świetle nowych badań technologicznych, historycznych i prac konserwatorskich, red. Grażyna Bastek, Grzegorz Janczarski, 256-261. Warszawa: Muzeum Narodowe, 1999. 


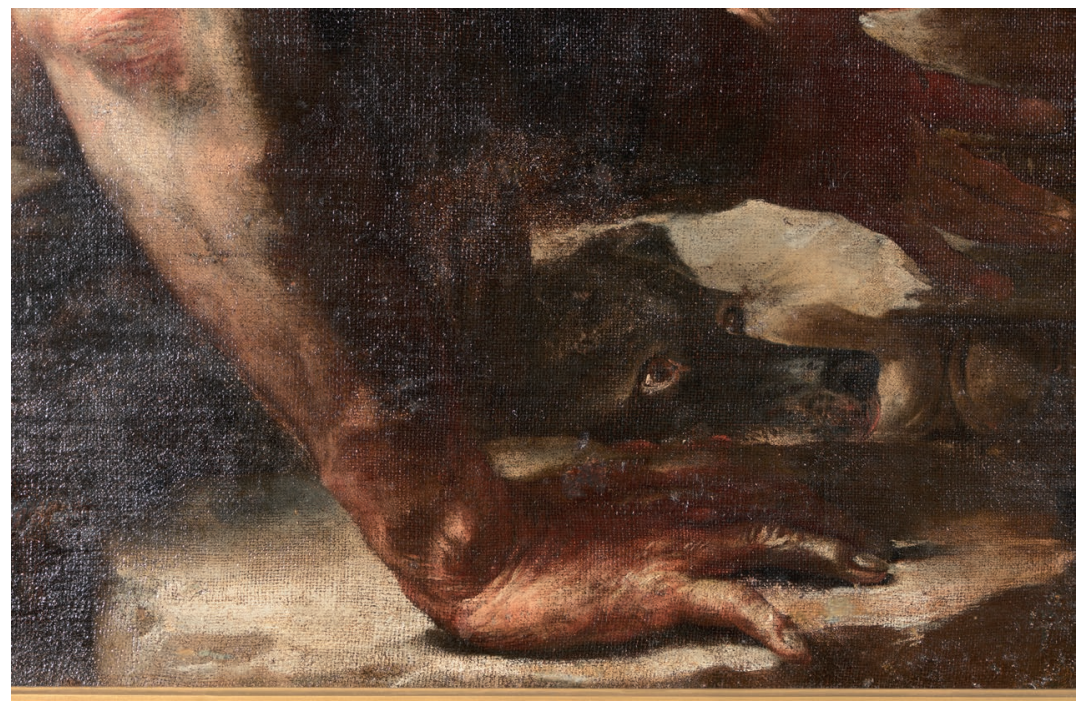

Fot. 1. Mattia Preti, Pokłon pasterzy, detal, widoczny gren płótna. Fot. R. Stasiuk

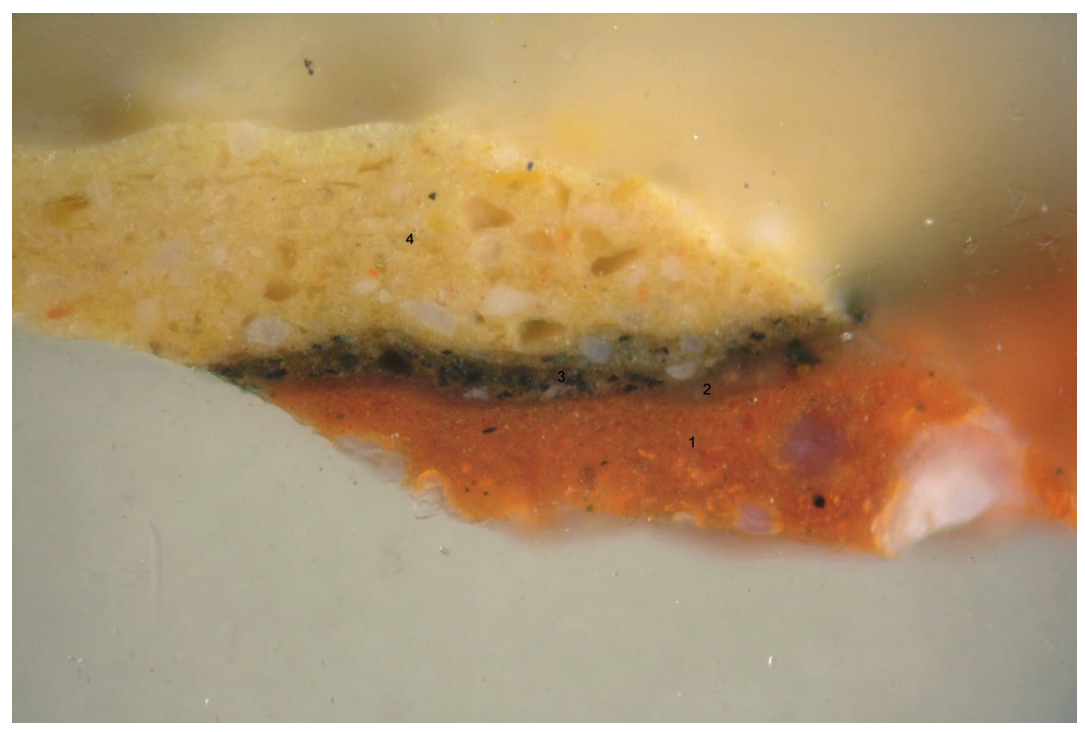

Fot. 2. Hendrick Ter Brugghen, Król Dawid grający na harfie w otoczeniu aniołów, mikrofotografie przekroju próbki z żółtego płaszcza. Fot. E. Jeżewska 




Fot. 3. Theodor Rombouts, Gra w karty, mikrofotografie przekroju próbki z partii czerwonego dywanu. Fot. E. Jeżewska

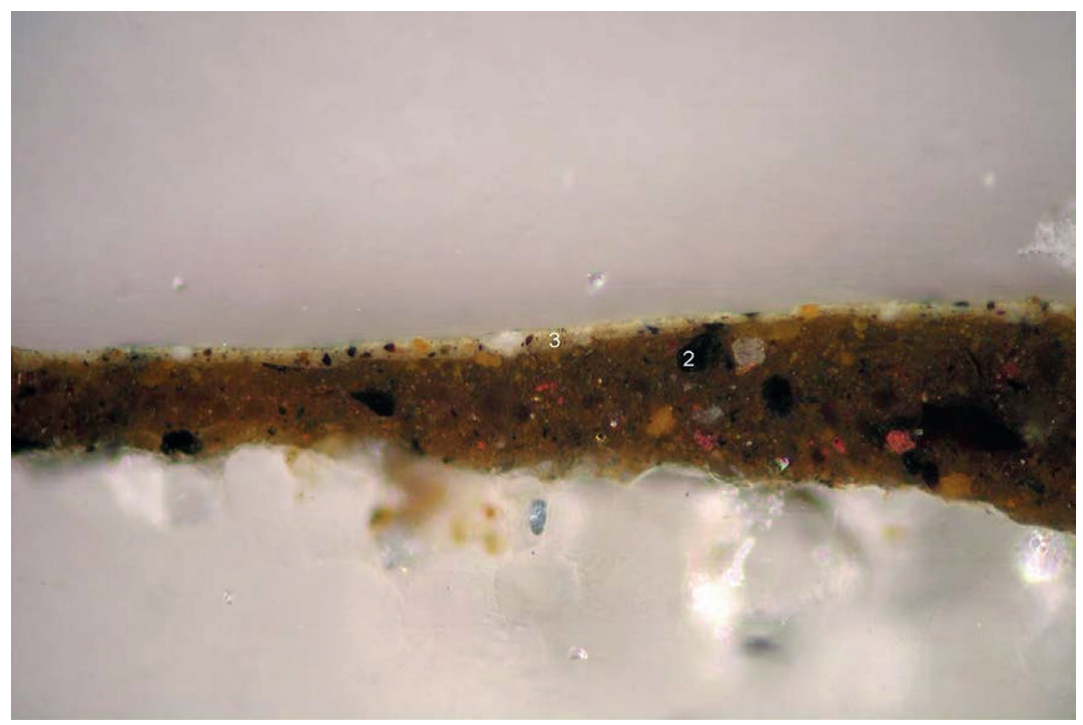

Fot. 4. Jusepe de Ribera, Św. Sebastian, mikrofotografie przekroju próbki z partii karnacji. Fot. E. Jeżewska 